\title{
28 Research Square \\ Standard Protocols for Flow Cytometry for monocytes, macrophages, DC and T cells
}

Paloma Riquelme ( $\square$ paloma.riquelme@klinik.uni-regensburg.de )

Department of Surgery, University Hospital Regensburg

James A. Hutchinson ( $\nabla$ james.hutchinson@klinik.uni-regensburg.de )

Department of Surgery, University Hospital Regensburg

Method Article

Keywords: flow cytometry, Mreg, miTreg, macrophage, T cell, IDO, Foxp3, Helios

Posted Date: July 11th, 2018

DOI: https://doi.org/10.1038/protex.2018.064

License: (9) This work is licensed under a Creative Commons Attribution 4.0 International License.

Read Full License 


\section{Abstract}

This document describes standard research protocols used for analysis of marker expression by flow cytometry in the Hutchinson work-group. In Riquelme et al., these protocols have been applied to the analysis of monocyte-derived macrophages, DC and cultured T cells.

\section{Introduction}

This document describes standard research protocols used for analysis of marker expression by flow cytometry in the Hutchinson work-group. In Riquelme et al., these protocols were applied to the analysis of monocyte-derived macrophages and DC, and cultured T cells.

\section{Reagents}

**General reagents** Biocoll Separating Solution \(L6115, Millipore-Biochrom) DPBS without $\mathrm{Ca}^{2+}$ or $\mathrm{Mg}^{2+} \backslash\left(\right.$ D8537, Sigma) BSA \(01400.1, Biomol) $\mathrm{NaN}_{3} \backslash($ S8032, Sigma) EDTA 0.5M \(15575-038, Gibco Life) Human FcR blocking reagent $\backslash(130-059-901$, Miltenyi) 7-AAD \(559925, BD) Intracellular fixation buffer $\backslash(00-8222$, eBiosciences) Permeabilization Buffer $\backslash(00-8333$, eBiosciences) FOXP3 Fixation/Permeabilization \(00-5521-00, eBiosciences) Fixable Live-Dead Viability DyeFluor660 \(650864, eBiosciences) Fixable Live-Dead Viability DyeFluor506 \(65-0866, eBiosciences) Faser Kit APC \ (130-091-762, Miltenyi) **Antibodies** Please see Table 1

\section{Equipment}

FACSCanto II cytometer: Standard configuration with 8 colour, 3 lasers \(BD Biosciences) DivaTM Software version v.6.1.3 \(BD Biosciences) Navios cytometer: Standard configuration with 10 colours, 3 lasers $\backslash$ (Beckman Coulter) Navios clinical software $\backslash$ (Beckman Coulter) FlowJoTM analysis software v.7.6.5 (FlowJo, LLC.) Kaluza analysis software v.1.0 \(Beckman Coulter)

\section{Procedure}

**1. REAGENT PREPARATION** $* * 1.1$ Preparation of FACS buffer** 1. Make stock solution of $10 \% \mathrm{NaN}_{3}$ in DPBS 2. Transfer $497 \mathrm{ml}$ DPBS to a Schott bottle 3. Add $1 \mathrm{ml} 10 \% \mathrm{NaN}_{3}$ solution to DPBS for an end concentration of $0.02 \% \mathrm{NaN}_{3} 4$. Add $2 \mathrm{ml} 0.5 \mathrm{M}$ EDTA to give an end concentration of $2 \mathrm{mM} 5$. Add $5 \mathrm{~g}$ BSA and allow to dissolve 6 . Store solution at $4^{\circ} \mathrm{C} * * 2$. PROTOCOLS FOR CELL-SURFACE STAINING OF MACROPHAGES, DC AND T CELLS $* \star \star \star 2.1$ Standard extracellular staining protocol** 1 . Harvest cells into cold DBPS. $2 \times 10^{5}$ cells are required for each staining reaction. 2 . Pellet cells by centrifugation at $300 \mathrm{~g}$ for 6 min 3. Aspirate supernatant using vacuum pump 4. Resuspend cells in $100 \mu \mathrm{l} /$ reaction of FACS buffer $+10 \%$ FcR block 5 . Incubate at $4^{\circ} \mathrm{C}$ for 30 min 6 . Transfer blocked cell suspensions into FACS tubes at $100 \mu \mathrm{l} /$ tube 7 . Add primary antibodies as indicated 8 . Incubate at $4^{\circ} \mathrm{C}$ in dark for $20 \mathrm{~min} 9$. Add 5 $\mu$ l 7-AAD per reaction. Incubate at $4^{\circ} \mathrm{C}$ in dark for $10 \mathrm{~min} 10$. Add $2 \mathrm{ml}$ DBPS per tube. Vortex 11. Pellet 
cells by centrifugation at $300 \mathrm{~g}$ for 6 min 12. Aspirate supernatant using vacuum pump. 13. Resuspend cells in $200 \mu \mathrm{l}$ DPBS for analysis by flow cytometry. $* \star 2.2$ Amplification of PE or APC signals using FASER kit ${ }^{\star \star} 1$. Harvest cells into cold DBPS. $2 \times 10^{5}$ cells are required for each staining reaction. 2 . Pellet cells by centrifugation at $300 \mathrm{~g}$ for 6 min 3 . Aspirate supernatant using vacuum pump 4. Resuspend cells in 100 $\mu \mathrm{l} /$ reaction of FACS buffer $+10 \%$ FcR block 5 . Incubate at $4^{\circ} \mathrm{C}$ for 30 min 6 . Transfer blocked cell suspensions into FACS tubes at $100 \mu \mathrm{l} /$ tube 7. Add primary PE or APC conjugated antibody as indicated 8. Incubate at $4^{\circ} \mathrm{C}$ in dark for $20 \mathrm{~min} 9$. Add $5 \mu \mathrm{l}$ 7-AAD per reaction. Incubate at $4^{\circ} \mathrm{C}$ in dark for $10 \mathrm{~min} 10$. Add $2 \mathrm{ml}$ DBPS per tube. Vortex 11. Pellet cells by centrifugation at $300 \mathrm{~g}$ for $6 \mathrm{~min} 12$. Aspirate supernatant using vacuum pump. 13. Resuspend cells in $80 \mu \mathrm{l} \mathrm{FACS} \mathrm{buffer}+20 \mu \mathrm{l} \mathrm{FcR} \mathrm{block}+10 \mu \mathrm{l}$ FASER reagent 114 . Incubate at $4^{\circ} \mathrm{C}$ in dark for $10 \mathrm{~min} 15$. Wash one time in $2 \mathrm{ml} \mathrm{DPBS}$ by centrifugation at $300 \mathrm{~g}$ for 6 min 16. Resuspend cells in $80 \mu \mathrm{l} \mathrm{FACS} \mathrm{buffer}+20 \mu \mathrm{l} \mathrm{FcR} \mathrm{block}+10 \mu$ FASER reagent 217. Incubate at $4^{\circ} \mathrm{C}$ in dark for $10 \mathrm{~min} 18$. Wash one time in $2 \mathrm{ml}$ DPBS by centrifugation at $300 \mathrm{~g}$ for 6 min 19. Resuspend cells in $80 \mu \mathrm{l} \mathrm{FACS} \mathrm{buffer}+20 \mu \mathrm{l} \mathrm{FcR} \mathrm{block}+10 \mu \mathrm{l} \mathrm{FASER}$ reagent 120 . Incubate at $4^{\circ} \mathrm{C}$ in dark for $10 \mathrm{~min} 21$. Wash one time in $2 \mathrm{ml}$ DPBS by centrifugation at $300 \mathrm{~g}$ for $6 \mathrm{~min} 22$. Resuspend cells in $80 \mu \mathrm{l} \mathrm{FACS} \mathrm{buffer}+20 \mu \mathrm{l} \mathrm{FcR}$ block $+10 \mu \mathrm{l} \mathrm{FASER} \mathrm{reagent} 2$ 23. Incubate at $4^{\circ} \mathrm{C}$ in dark for $10 \mathrm{~min} 24$. Wash one time in $2 \mathrm{ml}$ DPBS by centrifugation at $300 \mathrm{~g}$ for $6 \mathrm{~min} 25$. Resuspend cells in $200 \mu \mathrm{l}$ DPBS for analysis by flow cytometry. **3. INTRACELLULAR STAINING OF HUMAN MREGS FOR IDO** 1 . Harvest cells into cold DBPS. $5 \times 10^{5}$ Mregs are required for each staining reaction 2 . Pellet cells by centrifugation at $300 \mathrm{~g}$ for $6 \mathrm{~min} 3$. Aspirate supernatant using vacuum pump 4. Resuspend cells in $3 \mathrm{ml}$ DBPS 5 . Add $0.75 \mu$ Fixable Live-Dead dye 6 . Incubate at $4^{\circ} \mathrm{C}$ in dark for $30 \mathrm{~min} 7$. Wash one time in $10 \mathrm{ml}$ DPBS by centrifugation at $300 \mathrm{~g}$ for 6 min 8 . Resuspend cells in $300 \mu$ FACS buffer $+10 \%$ FcR block for 15 min 9 . Transfer blocked cell suspensions into FACS tubes at $100 \mu \mathrm{l} /$ tube 10. Add primary PE-conjugated CD33 or isotype antibody as indicated in Figure $1 \backslash\left(3\right.$ reactions) 11 . Incubate at $4^{\circ} \mathrm{C}$ in dark for $30 \mathrm{~min} 12$. Wash samples one time in $2 \mathrm{ml}$ DPBS by centrifugation at $300 \mathrm{~g}$ for 6 min 13. Add $100 \mu$ IC Fixation Buffer for 30 min RT in the dark 14. Wash samples twice in $2 \mathrm{ml}$ Perm Buffer by centrifugation at $300 \mathrm{~g}$ for 6 min 15. Resuspend samples in $100 \mu$ l of FACS buffer $+10 \%$ FcR block for 15 min at $4^{\circ} \mathrm{C} 16$. Add intracellular staining antibodies as indicated for $30 \mathrm{~min}$ at RT in the dark 17. Wash samples once in $2 \mathrm{ml}$ Perm Buffer by centrifugation at $300 \mathrm{~g}$ for $6 \mathrm{~min} 18$. Resuspend cells in $200 \mu \mathrm{l}$ DPBS for analysis by flow cytometry See figure in Figures section. $*$ * . INTRACELLULAR STAINING OF HUMAN TREGS FOR FOXP3 AND HELIOS $* * * 4.1$ Intracellular staining of cultured T cells ${ }^{\star *} 1$. Harvest cells into cold DBPS. $5 \times 10^{5}$ cells are required for each staining reaction 2 . Pellet cells by centrifugation at $300 \mathrm{~g}$ for $6 \min 3$. Aspirate supernatant using vacuum pump 4. Resuspend cells in $1 \mathrm{ml}$ DBPS 5. Add $1 \mu \mathrm{l}$ Fixable Live-Dead dye 6. Incubate at $4^{\circ} \mathrm{C}$ in dark for $30 \mathrm{~min} 7$. Wash one time in $10 \mathrm{ml}$ DPBS by centrifugation at $300 \mathrm{~g}$ for 6 min 8 . Resuspend cells in $100 \mu \mathrm{l}$ FACS buffer $+10 \%$ FcR block for 15 min 9 . Transfer blocked cell suspensions into FACS tubes at $100 \mu \mathrm{l} /$ tube 10. Add cell surface antibodies as indicated in Figure 211 . Incubate at $4^{\circ} \mathrm{C}$ in dark for $30 \mathrm{~min} 12$. Wash samples one time in $2 \mathrm{ml} \mathrm{DPBS}$ by centrifugation at $300 \mathrm{~g}$ for $6 \mathrm{~min} 13$. Aspirate supernatant using vacuum pump. Gentle vortex 14. Add $500 \mu$ l Fixation/Permeabilization 15. Incubate at $4^{\circ} \mathrm{C}$ in dark for $30 \mathrm{~min} 16$. Wash samples in $2 \mathrm{ml}$ Perm Buffer by centrifugation at $300 \mathrm{~g}$ for 6 min 17. Add intracellular staining antibodies $\backslash$ (FoxP3-PE, optional Helios-APC) as indicated 18. Incubate for $30 \mathrm{~min}$ at $4^{\circ} \mathrm{C}$ in the dark 19. Wash samples 3 times in $2 \mathrm{ml}$ Perm Buffer by centrifugation at $300 \mathrm{~g}$ for 
6 min 20. Resuspend cells in $200 \mu$ Perm Buffer for analysis by flow cytometry See figure in Figures section. $* * 4.2$ Intracellular staining for FoxP3 in T cells from clinical blood samples ${ }^{\star *} 11 \mathrm{ml}$ blood is used for each staining reaction. Dilute blood 1:1 with DBPS 2 Layer blood carefully onto $6 \mathrm{ml}$ Biocoll in a $15 \mathrm{ml}$ tube 3 Centrifuge at $2000 \mathrm{rpm}, 20^{\circ} \mathrm{C}$, for $25 \mathrm{~min}$ with no brake 4 Recover cell layer in the interface 5 Wash with $14 \mathrm{ml}$ DPSB by centrifugation at $1600 \mathrm{rpm}$ for $10 \mathrm{~min} 6$ Aspirate supernatant using vacuum pump 7 Resuspend cells in $100 \mu \mathrm{l} /$ reaction of FACS buffer $+10 \%$ FcR block 8 Incubate at $4^{\circ} \mathrm{C}$ for 30 min 9 Transfer blocked cell suspensions into FACS tubes at $100 \mu \mathrm{l} /$ tube 10 Add cell surface antibodies as indicated in Figure 311 Incubate at $4^{\circ} \mathrm{C}$ in dark for 30 min 12 Add $2 \mathrm{ml}$ DBPS per tube. Vortex 13 Pellet cells by centrifugation at $300 \mathrm{~g}$ for 6 min 14 Aspirate supernatant using vacuum pump. Gentle vortex 15 Add $500 \mu \mathrm{l}$ Fixation/Permeabilization 16 Incubate at $4^{\circ} \mathrm{C}$ in dark for 30 min 17 Wash samples in $2 \mathrm{ml}$ Perm Buffer by centrifugation at $300 \mathrm{~g}$ for 6 min 18 Add intracellular staining antibodies as indicated 19 Incubate for $30 \mathrm{~min}$ at RT in the dark 20 Wash samples 3 times in $2 \mathrm{ml}$ Perm Buffer by centrifugation at $300 \mathrm{~g}$ for 6 min 21 Resuspend cells in $200 \mu \mathrm{l}$ Perm Buffer for analysis by flow cytometry See figure in Figures section. $* \star 5$. Gating strategy for identifying TIGIT $^{+}$Tregs among NSG mouse splenocytes ${ }^{\star \star}$ See figure in Figures section.

\section{References}

1. Hutchinson J.A. et al. MITAP-compliant characterization of human regulatory macrophages. Transpl Int. 30\(8):765-775 \(2017). 2. Hutchinson J.A. et al. Cutting Edge: Immunological consequences and trafficking of human regulatory macrophages administered to renal transplant recipients. J Immunol. 1;187\(5):2072-8 \(2011) 3. Hutchinson J.A. et al. Human regulatory macrophages. Methods Mol Biol. 677:181-92 \(2011)

\section{Figures}




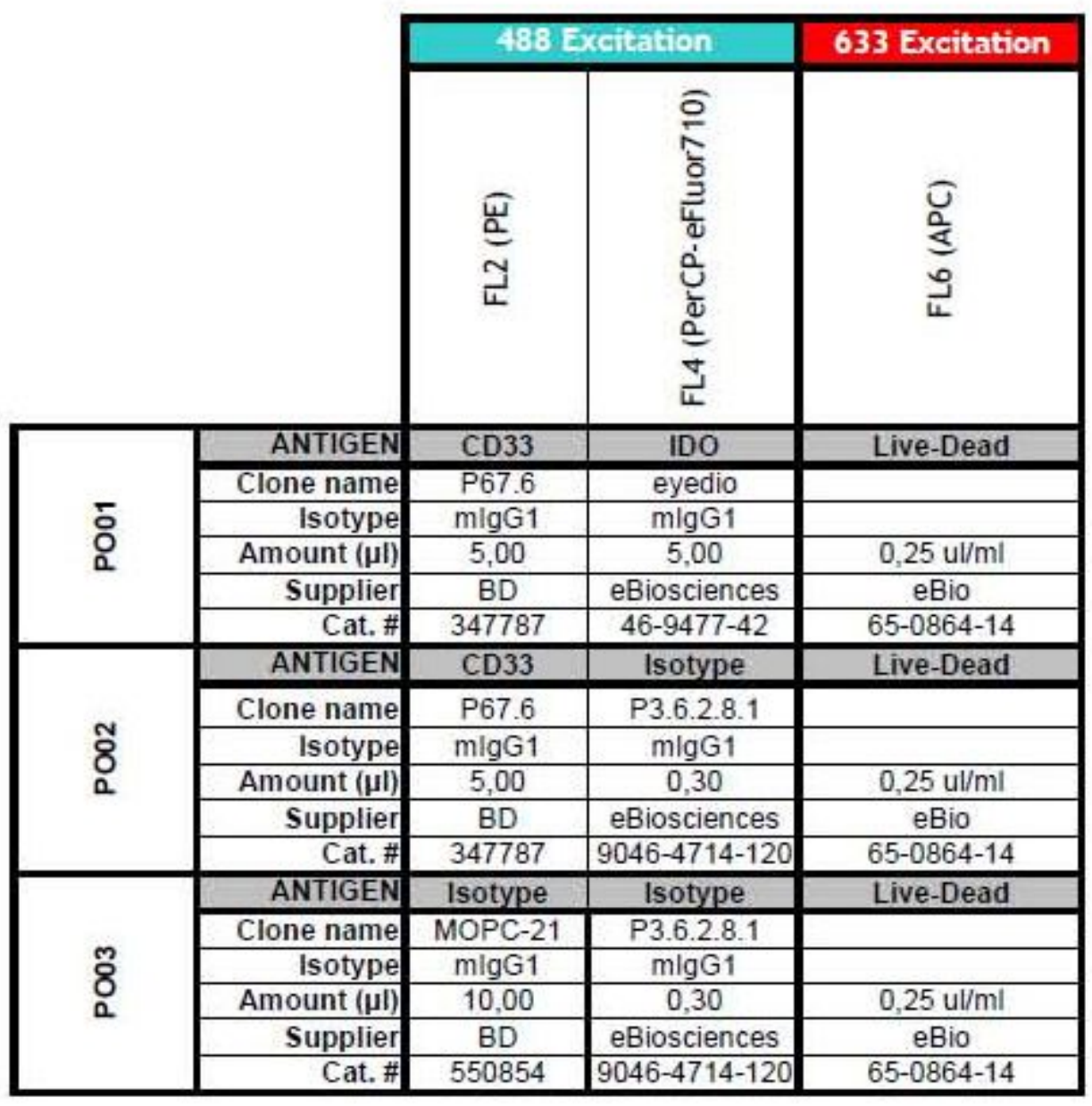

\section{Figure 1}

Staining panel IDO

\begin{tabular}{|c|c|c|c|c|c|c|c|c|c|}
\hline & & \multicolumn{4}{|c|}{488 Excitation } & \multicolumn{2}{|c|}{633 Excitation } & \multicolumn{2}{|c|}{405 Excitation } \\
\hline & & $\frac{\widehat{U}}{\underline{\underline{E}}}$ & $\begin{array}{l}\widehat{u} \\
\stackrel{u}{a} \\
\frac{u}{u}\end{array}$ & 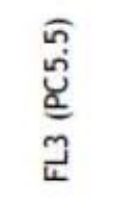 & 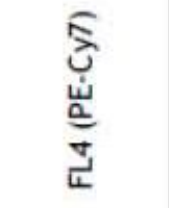 & 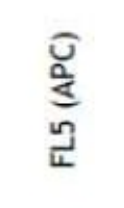 & 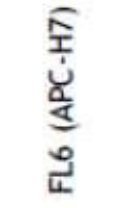 & 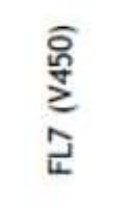 & 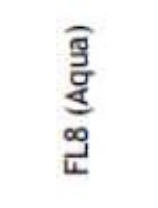 \\
\hline \multirow{7}{*}{ 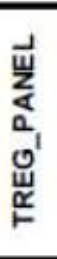 } & ANTIGEN & CD8 & FOXP3 & $\mathrm{CD} 3$ & TIGIT & Drop-in & $\mathrm{CD25}$ & $\mathrm{CD} 4$ & Live-Dead \\
\hline & Clone name & SK1 & $\mathrm{PCH} 101$ & SK7 & MBSA43 & & M-A251 & $\overline{\text { RPA-T4 }}$ & \\
\hline & Isotype & $\mathrm{mlg} G 1 \mathrm{k}$ & rat lgG2ak & $\mathrm{mlgG} 1 \mathrm{k}$ & $\mathrm{migG1}$ & & $\mathrm{mlgG} 1 \mathrm{k}$ & $\mathrm{mlgG} 1 \mathrm{k}$ & \\
\hline & Amount $(\mu \mathrm{l})$ & $20 \mathrm{ul}$ & 10 ul & 20 ul & $10 \mathrm{ul}$ & & 5 ul & 5 ul & + \\
\hline & Supplier & $\mathrm{BD}$ & eBio & $\mathrm{BD}$ & eBio & & $\mathrm{BD}$ & $\mathrm{BD}$ & eBio \\
\hline & Cat. \# & 345772 & $12-4776-42$ & 332771 & $25-9500-42$ & & 560225 & 560345 & \\
\hline & Status & CE/IVD & RUO & CE/IVD & RUO & & RUO & RUO & \\
\hline
\end{tabular}

Figure 2 


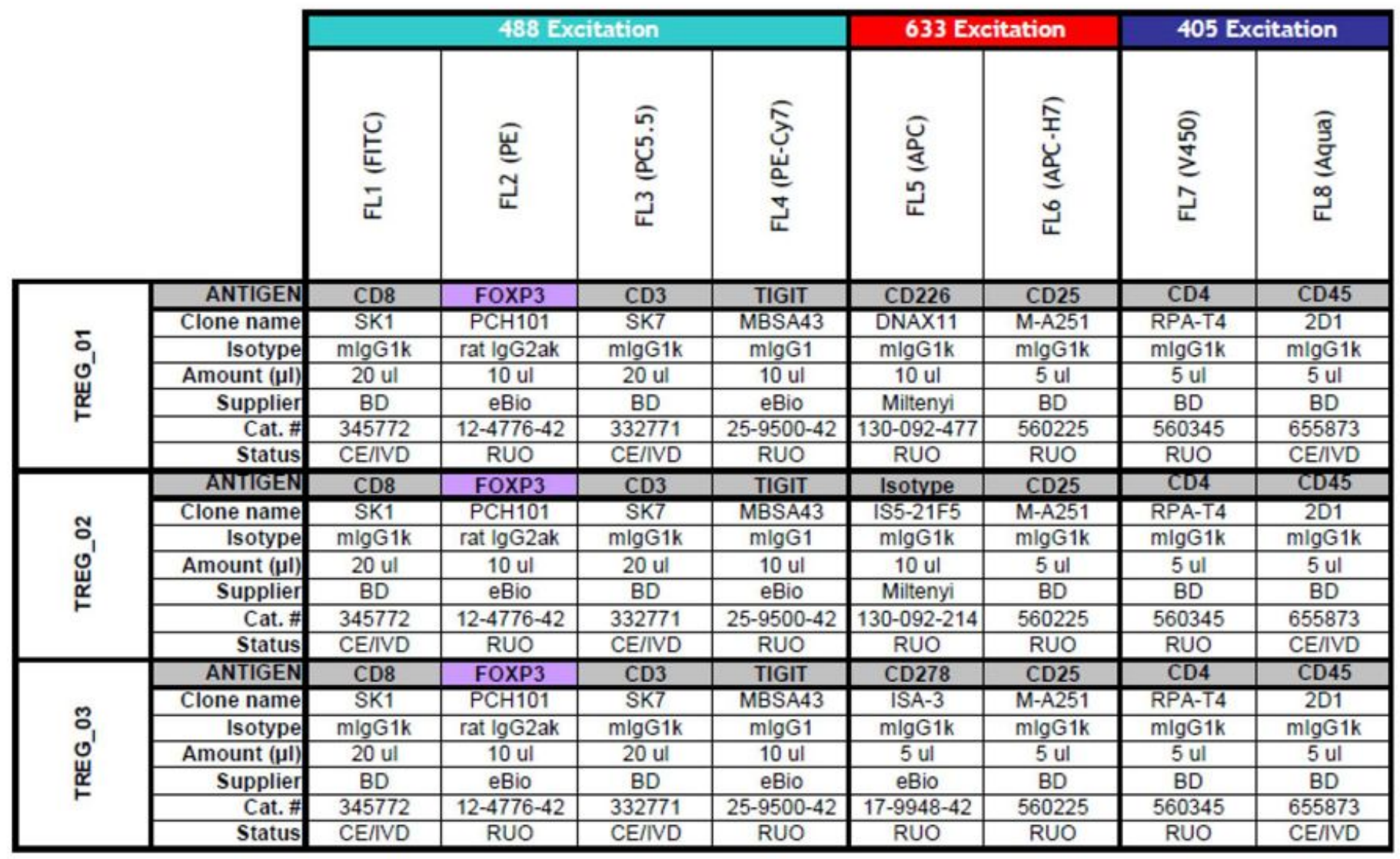

\section{Figure 3}

Staining panel iTreg in peripheral blood 

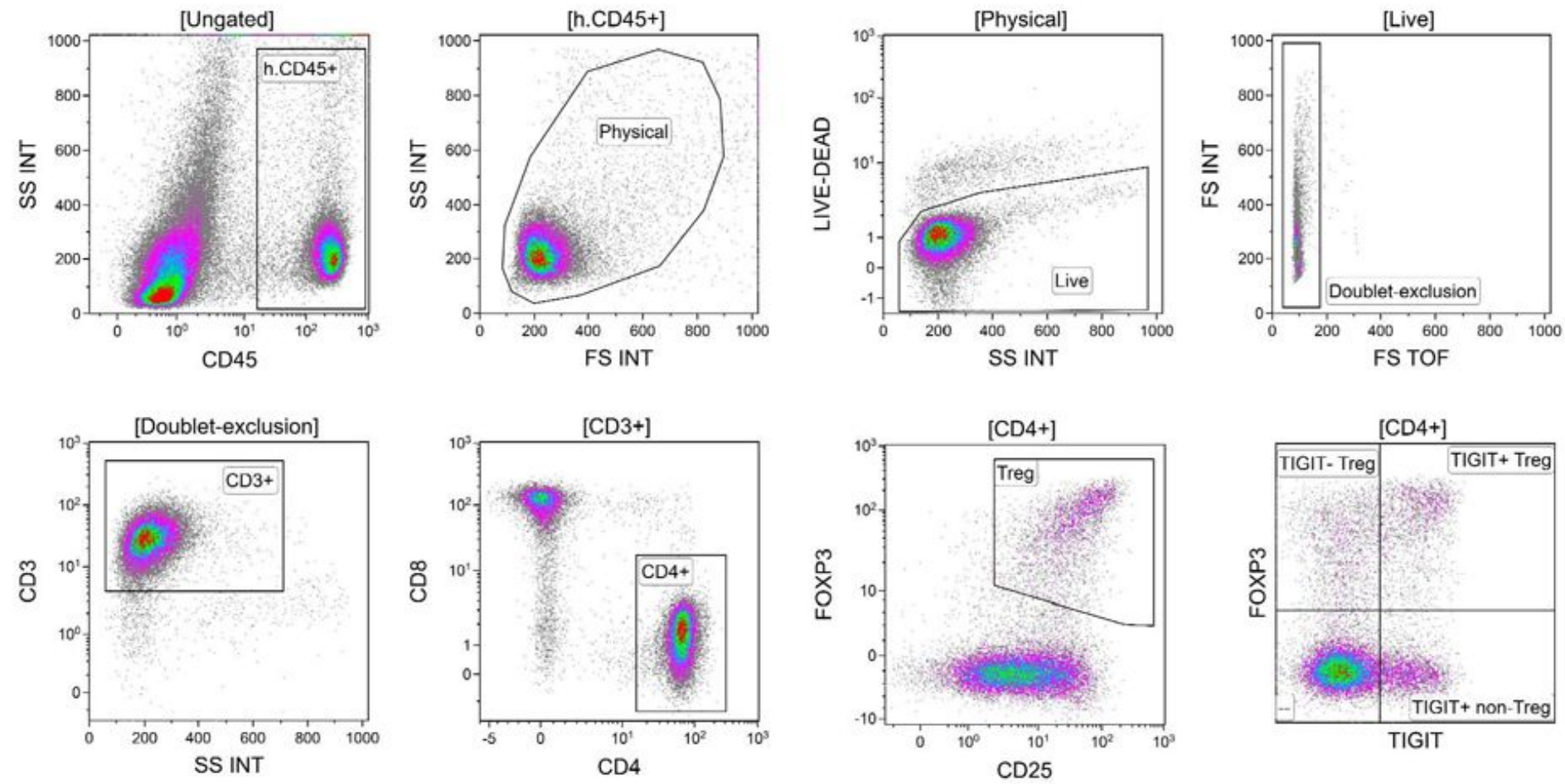

Figure 4

Gating strategy for identifying $\operatorname{TIGI}^{\wedge}+^{\wedge}$ Tregs among NSG mouse splenocytes

\section{Supplementary Files}

This is a list of supplementary files associated with this preprint. Click to download.

- supplement0.pdf 